\title{
Non-traditional Types of Youth Tourism and Developing Problems of Tourism
}

\author{
Nurbek Jabbarov \\ Department of Tourism, Tourism and Economics Faculty, Urgench State University, Urgench City, Uzbekistan \\ Email address: \\ goodluck_0714@mail.ru \\ To cite this article: \\ Nurbek Jabbarov. Non-traditional Types of Youth Tourism and Developing Problems of Tourism. Journal of Investment and Management. \\ Vol. 7, No. 3, 2018, pp. 77-80. doi: 10.11648/j.jim.20180703.11
}

Received: June 26, 2018; Accepted: July 7, 2018; Published: July 27, 2018

\begin{abstract}
In the article, nonconventional types and the basic problems of development of youth travel are considered. Thus, authors treat youth travel as an innovative direction of development of recreational sphere. Except for the presence of various tourist-recreational resources of the country allows developing almost all kinds of youth travel. The decision of this problem along with spiritual improvement of the nation is one of strategic problems, both on republican, and at regional level. Actual the problem of working out of the adaptive approach to the organization of tourist service of youth in Republic Uzbekistan thereupon is. The satisfaction of these requirements in the conditions of realization of social control should become priority from the state and accessible to youth. Participation in tourist campaigns, walks, country excursions, tourist meetings and competitions promotes spiritual and physical development, give skills of self-organizing, expand an outlook of the person and promote its improvement. It is necessary to notice also that amateur and sports tourism is as much as possible accessible to youth. Besides, tourism can be rather profitable branch of economy.
\end{abstract}

Keywords: Youth Travel, Unusual Tourism, State Social Policy, Sports Tourism

\section{Introduction}

The youth is the socially demographic group enduring the period of formation of a social maturity, adaptation to the world of adults and the future changes. The youth age represents as though «the third world», existing between the childhood and взрослостью, has mobile borders of the age (as a rule it is the period of life from 14 till 29 years) which depend on social and economic development of a society, level of culture, living conditions in the country. The youth has a number of the socially psychological features following, first of all, from its most objective essence: the raised emotional activity; physical mobility; dynamic change of moods; a visual and intellectual susceptibility. Features of youth also are defined by a specific position with which it occupies in the course of reproduction of social structure of a society, and also ability not only to inherit, but also to transform developed public relations. The contradictions arising in this process underlie the whole complex of specific youth problems [1-4].

Now new tendencies in a society way of life as a whole make considerable impact on a choice of forms of carrying out of youth leisure and rest. Such factors as demographic features of youth, their individual and group interests, the relation to free time carrying out, have changed character of youth demand and have led to creation of a new kind of rest of young men - youth travel. Undoubtedly, youth travel is one of welfare mechanisms with which help conditions for occurrence and disclosing of human abilities and requirements of youth for exhibiting of new possibilities and ways of their use in public life can created. As it is underline in many works reflecting problems of youth travel, it combines spontaneous activity of youth with the organized activity of establishments of tourist-excursion service. Now youth travel is the industry developing and offering various types of excursions, routes, rounds and a complex of the animation programs which consumption should organize activity of youth, having directed it on the improvement, the socially authorized forms of entertainment and education.

\section{Method}

Distinctive feature of youth travel is that youth - the most unpretentious socially demographic group which quality and a 
degree of service to a lesser degree interest. Comfortable conditions of residing and transportation are unessential to youth on a tourist trip, it reasonable prices and the sated game activity grasping mentality entirely, giving constant inflow to emotions and the new sensations meeting their age requirements in a greater degree interest. It is necessary to notice especially that interest to game activity at youth has strongly pronounced character. The range of these interests is wide and diverse. In today's uneasy social and economic conditions, the game world makes serious impact on youth. This world provides youth daily occurrence interruption. In process of loss of orientation to work and other values, the youth leaves in game, moves to space of the virtual worlds. Numerous supervision over practice of preparation and carrying out various youth досуговых actions testify that their success appreciably depends on inclusion in them of the game blocks stimulating at young men aspiration to improvisation and an ingenuity. The researchers conducted by authors have revealed various requirements of modern youth for carrying out of the leisure and rest. Besides traditional kinds of the organized youth travel (beach, informative, entertaining, etc.), based on motivation depending on the trip purposes, there are also nonconventional kinds which reflect game youth interests and satisfy their specific psychological requirements for self-expression and the statement. We will consider some of them [5-6].

Dark-tourism (from English dark - gloomy, dark) - the organized trips on cities-phantoms with all equipment necessary for their visiting and equipment. Cities-phantoms are the settlements left by the population for the reasons of recession of economic activity, wars, natural and technogenic accidents. Very many left cities become popular tourist objects. As an example it is possible to result one-day excursions, организуемые 24 years later after the most terrible in the world of nuclear failure in the center of accident on the Chernobyl atomic power station located less than in hundred kilometer's from Kiev. The trip program includes courses on respirator and gas mask application, rendering of the first medical aid, conversation with representatives of specialized agency «Chernobyl Interinform», a stop near to a sarcophagus of fourth reactor and «a non-polluting dinner» with quality check of products by a dosimeter. In Pripyat tourists visit a cemetery of the infected technics, have possibility to meet inhabitants of the infected villages - so-called «itself villages», половить fish in the channel near to nuclear station.

Ritual tourism - visiting of cemeteries and tombs of the ancestors on places of the historical residing with the ritual purposes, and also excursions to the thrown and ancient cemeteries.

Industrial tourism - research of territories, buildings and various engineering constructions of industrial or economic appointment, and any thrown constructions for the purpose of reception of psychological satisfaction and research interest. Many lines of youth subculture prove this kind of tourism and «city research» (from English urban exploration) or «stalkers» called. In countries of Western Europe industrial tourism has received popularity in the early eighties after mass media have paid attention to it, and has reached popularity musical style «industrial» which collectives «Throbbing Gristle», «Current 93», «Einstrzende Neubauten», «Coil», «Nurse With Wound» concern. In the USSR the great interest was showed to a similar original aesthetics of the thrown objects and industrial zones after occurrence of a film of director Andrey Tarkovsky "Stalker", and fans of industrial tourism began to name themselves stalkers. The wide circulation of the given kind of industrial tourism connected with rather small risk for health (danger sudden collapses of designs, asbestos and other chemical pollution can represent) and usually absence of protection of objects [7-8].

One of kinds of industrial tourism, the most extreme and demanding more serious preparation, equipment and certain level of the adventurism connected with danger, is infiltration - penetration on protected territories, territories of operating industrial zones and the zones which have been not created for a finding in them of people. Reception of adrenaline and special psychological satisfaction from visiting closed for extraneous zones becomes an overall objective of such hobby.

\section{Result}

On tablets «the input is prohibited an inscription by the stranger», «the exit is not present», "fire escape", «show the admission» and «danger, to enter» not begin direct instructions to opposite actions. Other kind of industrial tourism - urban caving (from English to dig - to dig) research of underground constructions, such, as drainage systems, sewer collectors, the underground rivers, industrial tunnels, ghost-stations in the underground tunnels. The thrown and functioning bombproof shelters, cellars, old mines, etc. it is not necessary to confuse diggers with tunnels which purpose is research caves, stone quarries and caves of an artificial origin. St.-Petersburg - one of the most attractive cities of the Russian Federation for such kinds of industrial tourism, as urbanism and roofing. Urbanism (from English urban - city) - interest to the specific city landscapes generated as a result of expansion, development or, on the contrary, arrival to decline of city territories. Objects are city courtyard - wells, deadlocks, road outcomes and depot, landscapes of the dormitory areas, not used roads, strange and unusual places in city areas. In many EU countries the tourist firms offering similar specialized rounds on not advertised corners of such cities, as Prague, Rome, Toledo, Granada and etc. Roofing (from English roof - a roof) contemplation of the kinds opening from city roofs operate.

And one more kind of nonconventional youth travel connected with subculture - cyber-goth-tourism - tourism «for people of the future» which consider that in connection with bad ecology, increase in mechanization and a computerization will soon come to human lives time nuclear and nuclear catastrophes when all will disappear live and they can survive only. For their appearance, clothes and respirators are characteristic synthetic and латексная. Cyber- 
goth (from English cyber - computers, the Internet, cybernetics, artificial intelligence; Goth - apathy, death, gothic music) have adopted elements from gothic subculture and cyber-culture. The earliest reference to term occurrence "Cyber-goth" founded in the book about a role-playing game of "Cyber-goth" which have been let out in 1990 of the Trip of campaigns. Cyber - is ready on the vaults, to not completed buildings and other objects of the industrial mean not its studying, and the organization and carrying out of photo sessions on such objects. Thus, it is possible to conclude that youth travel in all its traditional both nonconventional kinds and forms is the welfare mechanism with which help conditions for satisfaction of the organization of youth leisure and rest can be created.

\section{Discussion}

Thus, there are some problems of development of youth travel. As above specified, the youth is an important condition, the factor of social changes, and innovative force, it not only object of influence from a society and the state, but also potentially the most vigorous, innovative and radical subject of social development. At the same time youth at the age from 14 till 30 years as one of socially not protected groups, is to the full subject to influence of negative factors of environment. The urbanization, the limited possibilities for high-grade development and realization of the potential, stressful situations cause the raised requirement in youth in accessible improving, recreational, entertaining services [9-10].

In the world, there was a whole infrastructure of youth travel. It has received certain development and in Republic of Uzbekistan. In the state the chain youth хостелов operates, and discounts for youth at the food enterprises, on transport and in other establishments are given. However, the current state of system of youth travel does not meet the international requirements and demands steadfast attention to itself. The error in this case consists or in full ignoring of specificity of youth travel as that, or in inability to build up rational and adequate system of tourist service of the youth, considering all features of the given segment of the market.

\section{Conclusion}

As the social branch, tourism can be engaged in preparation of the high-grade, harmoniously developed citizens. Education of the citizen of the country a long-term and versatile problem. In our country, more than $80 \%$ of youth do not presume or is not able to organize to itself qualitative rest and active pastime. Tourism is capable to create conditions for youth involving in employment by mass sports, familiarizing with a healthy way of life, development of patriotic sentiments, is capable to cope with the majority of educational problems of rising generation. Participation in tourist campaigns, walks, country excursions, tourist meetings and competitions promotes spiritual and physical development, give skills of self-organizing, expand an outlook of the person and promote its improvement. It is necessary to notice also that amateur and sports tourism is as much as possible accessible to youth. Besides, tourism can be rather profitable branch of economy.

At annually increasing requirement of youth to employment by tourism, problems of development of tourism various state departments are engaged, there is no uniform base on human life problems in environment, there is a deficiency of the qualified tourist shots, routes and the technologies capable qualitatively to satisfy a growing demand, the material resources of amateur tourism are weak.

Proceeding from the previously mentioned, it is necessary:

1. Creation of the working model of the centers, bases and camps children's and youth travel in regions of Uzbekistan.

2. Association of departments and the organizations, which are taking up the problems of tourism, carrying out of joint actions under the aegis of the State Committee on youth affairs.

3. Increase of image of the country as object of tourism.

4. Attraction to work of the people professionally understanding problems of tourism.

5. Youth travel development in regions, the organization of republican both regional interaction and control over realization of activity within the limits of youth travel at republican and regional levels.

6. Creation of base of the public organizations closely cooperating with regional enforcement authorities on affairs of youth.

7. Carrying out of mass tourist actions.

8. The organization of work of tourist sections, tourist competitions, tourist routes for youth.

9. A solution of a problem of deficiency of tourist shots, increase профессионализации tourist branch.

10. Maintenance with shots of regional and international tourist actions.

The developed youth travel will have notable educational influence on rising generation. It is important as its improving, medical and preventive aspects: it helps children and young men got stronger and healthy to continue educational process in schools, technical training colleges and higher educational institutions. If in common to solve these problems that, youth of our country can travel all over the world, but thus there are some problems before the government and youth. In due course, our country will find a place in world youth travel.

\section{References}

[1] Non-traditional types of tourism https://www.skyscanner.ru/news/12-neobychnykh-vidovturizma

[2] Alikulova, A. (2014). Tourism impact on improvement of population welfare in Kazakhstan. Actual Problems of Economics, 155(5), 290-298.

[3] Banerjee, A., Ye, X., \& Pendyala, R. M. (2007). Understanding travel time expenditures around the world: Exploring the notion of a travel time frontier. Transportation, 34(1), 51-65. https://doi.org/10.1007/s11116-006-0004-6 
[4] Baum, T., \& Thompson, K. (2007). Skills and labour markets in transition: A tourism skills inventory of Kyrgyzstan, Mongolia and Uzbekistan. Asia Pacific Journal of Human Resources, 45(2), 235-255. https://doi.org/10.1177/1038411107073601

[5] Beaumont, N., \& Dredge, D. (2010). Local tourism governance: A comparison of three network approaches. Journal of Sustainable Tourism, 18(1), 7-28. https://doi.org/10.1080/09669580903215139

[6] Cornell, T. J. (1975). Travel in the ancient world. Journal of Historical Geography. https://doi.org/10.1016/03057488(75)90127-9

[7] Elias, W., Benjamin, J., \& Shiftan, Y. (2015). Gender differences in activity and travel behavior in the Arab world. Transport Policy, 44, 19-27.

https://doi.org/10.1016/j.tranpol.2015.07.001
[8] International, I. (2011). ITB World Travel Trends Report 2010/2011. World, 01-30. https://doi.org/http://www.itbberlin.de/media/itb/itb_dl_de/itb_itb_berlin/itb_itb_academy/I TB_2015_WTTR_Report_A4_4.pdf

[9] Liu, Q., Ge, Y., Li, Z., Chen, E., \& Xiong, H. (2011). Personalized travel package recommendation. In Proceedings - IEEE International Conference on Data Mining, ICDM (pp. 407-416). https://doi.org/10.1109/ICDM.2011.118

[10] World Travel \& Tourism Council. (2015). Travel \& Tourism. World Travel \& Tourism Council. Retrieved from http://www.invest.gov.tr/en-

US/infocenter/publications/Documents/TOURISMINDUSTRY.pdf 